Ks. Stanislaw Wlodarczyk

\title{
ZWIASTOWANIE MARYI ZAPOWIEDZIĄ NADEJŚCIA „PEKNI CZASÓW”
}

\author{
ZBAWCZA INICJATYWA BOŻA
}

Od początku historii zbawienia zawsze wychodzi pierwszy $z$ inicjatywą zbawczą Bóg. W Liście do Hebrajczyków 1, $1-2$ czytamy: ,wielokrotnie i na różne sposoby przemawiał niegdyś Bóg do ojców przez proroków, a w tych ostatecznych dniach przemówił do nas przez Syna”. Może spontanicznie nasunąć się pytanie, jak Bóg-Byt transcendentny przemawiał do ludzi, komunikując im prawdy zbawienia?

Wiemy z filozofii, że świat transcendencji-świat Boga ma swoją własną, odrębną strukturę ontologiczną, inną zasadniczo od ludzkiego sposobu bytowania. Więc słusznie się rodzi pytanie, czy można w tym świecie transcendencji znaleźć miejsce na tę ,ludzką" właściwość mowy Bożej? To zagadnienie rozwiązuje tzw. teoria synkatabasis ${ }^{1}$. Według niej Bóg ,mówiąc” do ludzi, zniżył się do nich, zniżył się do ich sposobu myślenia, do ich zwyczajnego języka. Twórca teorii św. Jan Chryzostom w komentarzu do $\mathrm{Rdz} 2,2$ pisze: „... Pismo św. mówi do nas językiem ludzkim, by zniżyć się do nas, przekazać nam jak najwięcej dobra" (In Gn. Hom. 13, 5; PG 53, 109).

Bóg w przekazywaniy prawd zbawczych posługiwał się ustami proroków. W Kșiędze Powtórzonego Prawa 18, 18 czytamy: „Wzbudzę im proroka spośród ich braci, takiego jak ty, i włożę w jego usta moje słowa, będzie im mówił wszystko, co rozkażę". Oprócz tego, Bóg objawiał swoje prawdy zbawcze przez wizje, sny, zdarzenia, ludzi, aniołów itd.

W najbardziej dramatycznych chwilach, kiedy człowiek pogardził Bożą miłością, słyszy zapowiedź zbawienia (zob. Rdz 3, 15). Zwiastowanie Maryi jest początkiem realizacji tej zapowiedzi, ,unieważni” te smutne konsekwencje wyrzucenia z Edenu-krainy szczęścia. Nastąpi przeobrażenié ludzkości, odnajdzie ona Boże życie, jak mówi Konstytucja Lumen gentium ( $\mathrm{rr} 53$ ): „Maryja Dziewica przy zwiastowaniu anielskim poczęła w sercu i w ciele Słowo Boże i dała światu życie".

Zwiastowanie Maryi jest ujęte w formę mająca na względzie ukazanie ekonomii zbawienia ${ }^{2}$. Stąd zwrócimy szczególną uwagę na te sformułowania, które wyrażają ideę zbawienia, które mają związek $\mathrm{z}$ całą historią zbawienia.

1 Zob. Ks. S. Włodarczyk, Rola synkatabasis $w$ interpretacji Pisma św. wedlug św. Jana Chryzostoma, RBL 4-5 (1974), 246-251.

2 Zob. B. Riga ux, Témoignage de l'évangile de Luc, Bruges 1970, s. 124 . 
W scenie zwiastowania pierwszy wychodzi z inicjatywą zbawczą Bóg, ,,posyłając anioła Gabriela do miasta w Galilei, zwanego Nazaret" $(1,26)$. Sw. Eukasz pisząc ewangelię dla nie-Żydów, określa dokładnie położenie miasta Nazaret, jakby chcąc powiedzieć, że to wielkie wydarzenie historiozbawcze miało miejsce $w$ konkretnej miejscowości, w Galilei - północnej części Palestyny. Nazaret nie jest wspomniane ani w Starym Testamencie, ani w pismach Józefa Flawiusza, wielkiego historyka żydowskiego ${ }^{3}$. Stąd może uzasadnione jest trochę pogardliwe pytanie Natanaela: „Czy może być co dobrego z Nazaret"? ( $J$ 1, 46). Ale urocze położenie miasta jakby wynagradzało tę jego nieznajomość i pogardę innych. Należy do najpiękniejszych w całej Galilei i może dlatego jest nazwane Nazaret, czyli „kwiatem” Galilei. Wykopaliska archeologiczne, a zwłaszcza prowadzone w 1955 roku przez szkołę biblijną franciszkańską, ujawniły Grotę Zwiastowania, zwaną Swiętą Grotą, przypuszczalne mieszkanie swiętej Rodziny ${ }^{4}$. Obok Groty Zwiastowania odnaleziono inne groty, w których dane archeologiczne wskazują, że zamieszkiwali tam ludzie już w VI wieku przed Chr. Archeologia biblijna wskazuje nie tylko na grotę, ale również na budowle pierwszych kościołów nad Grotą Zwiastowania. Już prawdopodobnie cesarz Konstantyn Wielki dla upamiętnienia miejsca zwiastowania buduje bazylikę, która potem zostaje zburzona przez Arabów, a odbudowana przez krzyżowców. Obecnie nad Grotą Zwiastowania wznosi się nowoczesna piękna bazylika - dar narodów świata chrześcijańskiego.

\section{ZAŚLUBINY MARYI Z JÓZEFEM (Ek 1, 27)}

$\mathrm{Na}$ zaślubiny Maryi $\mathrm{z}$ Józefem trzeba spojrzeć $\mathrm{w}$ podwójnym aspekcie: zbawczym i prawnym.

$\mathrm{Na}$ aspekt zbawczy wskazuje to, iż było to małżeństwo naznaczone specjalnym znakiem, na co wskazuje tekst: „Bóg posyła anioła... do Dziewicy poślubionej mężowi... (Łk 1, 27). I tutaj nasza myśl kieruje się do jednego $\mathrm{z}$ najważniejszych tekstów Starego Testamentu do $\mathrm{Iz} \cdot 7,14$, który ma związek z dwukrotną wzmianką w perykopie o zwiastowaniu mówiącą o dziewiczości Maryi (Łk 1, 27. 34) ${ }^{5}$. Nie wchodzimy w szczegółową analizę tekstu Iz 7, 14, który doczekal

3 Zob. Ks. H. Strąkowski, art. Nazaret, w: Podręczna Encyklopedia Biblijna, t. II, Poznań 1959, ss. 145-146; H. O berm a y e r, K. S pe i de l, art. Nazaret, w: Piccolo Dizionario Biblico, Tusculi 1973, s. 224.

4 Zob. B. Bagatti, Gli scavi di Nazaret, Jerusalem 1967; Antichi villaggi cristiani di Galilea, Gerusalemme 1971, ss. 20-37; Ks. H. Strąk ow s k i, art. cyt., s. 146.

5 Zob. Ks. J. Łach, Stużebna rola Maryi $w$ odkupieniu $w$ świetle relacji o zwiastowaniu ( $€ k$ 1, 26-38), RBL 6 (1981), 350; Ks. E. Z a w iszewski, Alma $i$ jej dziecię (Iz 7, 14), w: Mesjasz w biblijnej historii zbawienia, Lublin 1974, ss. 72-94. 
'się licznych. komentarzy, lecz pragniemy tylko .zwrócić uwagę na niektóre myśli ściśle wiążące się z pojęciem dziewictwa.

Zdaniem filologów idea dziewictwa nie jest ściśle związana ze słowem 'almāh, gdyż język hebrajski na określenie dziewicy zna' słowo betūlāh. Ale uwzlędniając sens obiegowy, zwyczajny słowa 'almāh w wypowiedziach Pisma św., można zdaniem biblistów wyciągnąc wniosek, że wyraz 'almāh nie bywał używany na oznaczenie niewiasty zamężnej. Gdyby ów wyraz nie oznaczał dziewicy, to w pojęciu Izraelitów nazwa ta miałaby znaczenie ogromnie zniesławiające. A zátem można by postawić twierdzenie, że jakkolwiek 'almāh w języku biblijnym oznacza w pierwszym rzędzie młodą niewiastę niezamężną, to jednak zawiera w sobie ideę dziewictwa. Septuaginta oddaje słowo ha 'almāh $z$ tekstu Iz 7, 14 przez parthenos, a łacińska Wulgata przez virgo. Jest to dowód, że tłumacz grecki i łaciński mieli na myśli dziewice $w$ znaczeniu ścisłym. Również bliższy i dalszy kontekst wypowiedzi Izajasza wskazuje, że prorok dlatego nazywa pannę ha' 'almāh, gdyż właśnie wyróżnia się tą szczególną właściwością, że została matką bez utraty dziewictwa i bez udziału mężczyzny ${ }^{6}$. To Izajaszowe: proroctwo spełniło się w scenie zwiastowania.

$\mathrm{Na}$ aspekt prawny wskazuje to, że małżeństwo Maryi z Józefem było zawarte. według obowiązujących przepisów żydowskich, według których składały się na nie trzy odrębne akty prawne: zaślubiny, uroczyste przeprowadzenie narzeczonej do domu narzeczonego i wspólne zamieszkanie ${ }^{7}$.

Zaślubiny według religijnych przepisów żydowskich uważano $\mathrm{zd}$ małżeństwo (zob. Pwt 22, 23), chociaż brakowało dwóch pozostałych elémentów prawnych. W chwili zwiastowania Maryja jeszcze nie przeprowadziła się do domu Józefa, o czym świadczy wyraźnie tekst Mt 1, 18: „Po zaślubinach Matki Jego, Maryi z Józefem, wpierw nim zamieszkali razem, znalazła się brzemienną za sprawą Ducha Swiętego". To jest znak, że Bóg wkracza tu z misją zbawczą.

\section{POCHODZENIE JÓZEFA Z RODU. DAWIDA (Łk 1, 27)}

Św. Eukasz wymieniając imię Józefa dodaje: „z rodu Dawida” $(1,27)$, chcąc tym samym nawiązać do przepowiedni i proroctw Starego Testamentu o rodzie, który ma odegrać ważną rolę w historii narodu wybranego, z ktởrego ma wyjść 'sławny potomek (zob. Psalmy mesjańskie).

${ }^{6}$ Zob. Ks. W. W inia'rski, Matka Najświętsza w Piśmie św., w: Gratia plena - Studia teologiczne o Bogurodzicy, Poznań 1965, s. 35; Ks. E. Z a w is z e w ski, art. cyt., ss. $80-81$.

7 Zob. A. Nicolas-Ks. E. Dąbrowski, Zycie Maryi Matki Bożej, Poznań-Warszawa $1964^{3}$, s. 96. 
Konstrukcja żania: ,... posłał Bóg anioła... do Dziewicy poślubionej mężowi, imieniem Józef, $z$ rodu Dawida; a Dziewicy było na imię Maryja" $(1,27)$ wskazuje, że słowa ,z rodu Dawida" odnoszą się do Józefa, gdyż mają bezpośrednią łączność z imieniem Józefa, a nie z następną częścią zdania, gdzie ezytamy o Maryi ${ }^{8}$. Poza tym przychodzi nam z pomocą ewangelia św. Mateusza 1, 20, gdzie anioł zwracając się do Józefa mówi wprost: „Józefie, synu Dawida”.

Gdy chodzi o pochodzenie Maryi z rodu Dawida, to trzeba stwierdzić, że nie ma wprost o tym wzmianki w ewangeliach czy w innych Pismach Nowego Testamentu. Możemy dopatrywać się aluzji w niektórych tekstach, np. u św. Eukasza 1, 32 czy w Liście do Rzymian 1, 3. O przynależności Jej do tego sławnego rodu mówią dopiero pisarze chrześcijańscy, jak św. Justyn, który w Dialogu 43 mówi, że Jezus jest narodzony $z$ Dziewicy, która jest $z$,pokolenia Abrahama, z pokolenia Judy i Dawida". Równieź św. Ignacy Antiocheński utrzymuje tę opinię.

\section{POCHODZENIE JEZUSA Z RODU DAWIDA ( 飞k 1, 32)}

W perykopie zwiąstowania posłaniec Boży oznajmia Maryi, że narodzony z Niej Syn: ,będzie wielki i będzie nazwany Synem Najwyższego, a Pan Bóg da Mu tron Jego praojca, Dawida” (Ek.1, 32). Przez to chce powiedzieć, że już wypełniły się zapowiedzi psalmów mesjańskich o sławnym Potomku z rodu, Dawida. W ten sposób dany zostą Maryi dowód, że Bóg poprzez swojego Syna, zasiądzie na tronie Dawida, aby dokonać jego wyzwolenia, zbawienia. Syn Boży zjawi się na świecie w rodzinie Dawidowej, gdyż Maryja jest, jak mówi tekst: „poślubiona mężowi, któremu na imię Józef, z domu Dawida" $(1,27)$. Maryja wierzy i jest świadoma tego, że jej Syn ma być rzeczywistym potomkiem z rodu Dawida dzięki nadaniu mu imienia przez ludzi i z woli Bożej. Posiądzie On tron Dawidowy w sposób prawnie mu należny, ale mimo to będzie On „rogiem zbawienia" nie z domu Dawida, tylko ,w" domu Dawida. To znaczy, że będzie On niejako bezpośrednio dany przez Boga dla Domu Dawidowege.

WVspomnianó powyżej, że dla Maryi jednym z argumentów przemawiających za pochodzeniem jej Syna z rodu Dawida jest nadanie dziecięciu imienia i to za sugestią Bożego wysłannika: „Oto poczniesz i porodzisz Syna, któremu nadasz imię Jezus" $(1,31)$. Powstaje pytanie, dlaczego aż tak silnie przywiązywano uwagę do imienia? Otóż dlał̌go, że na Starożytnym Wschodzie, a zwłaszcza w Biblii, imię wyrażało rolę, jaką dana osoba ma do spełnienia ${ }^{9}$. Ósmego dnia po

8 Zob. J. Cantinant, La Madonna nella Bibbia, Bari 1970, s. 55.

9 Léon-Dufour, art., Imię, w: Stownik Nowego Testamentu (tł. Ks. K. Romaniuk), Poznań 1981, ss. 298-299. 
urodzeniu dziecko otrzymywało od swoich rodziców lub od samego Boga imię. Imię Jezus, hebrajskie $\mathrm{Y}$ e hos z u a, a forma skrócona Y eszua znaczy „Jahwe zbawia” lub „Jahwe zbawił”. Biorąc pod uwagę Pismo św. Starego Testamentu uderza nas znamienny fakt, który bardziej jeszcze zilustruje znaczenie imienia, że tym imieniem Yeszua zostały obdarzone dwie osoby, które odegrały tak wielką rolę $\mathrm{w}$ historii zbawienia narodu wybranego: Jozue, przywódca izraelski w wędrówce do Ziemi Obiecanej, który obejmuje ten urząd po śmierci Mojżesza, i Jozue - kapłan żydowski, który wraca z grupą wygnańców po niewoli babilońskiej (zob. Ag 2, 1; Za 3, 1-10).

Można stąd wyprowadzić wniosek, że nadanie imienia Y eszua synowi Maryi ma ukazać ten ideowy związek powrotu do ziemi odzyskanej, czyli do tego, co się straciło.

\section{IMIE MARYI (乇k 1, 27)}

Św. Łukasz kreśląc plan zbawczy, jaki stoi przed Tym, którego Maryja ma wydać światu: ,będzie panował nad domem Jakuba na wieki, a Jego panowaniu nie będzie końca" (1,33), pragnie również poprzez imię Dziewicy - Maryja wskazać na jej rolę w dziele zbawczym, chce wskazać na powiązania $\mathrm{z}$ ekonomią zbawienia Starego Testamentu, gdyż to imię Maryja było znane w Biblii. Ludzie noszący to imię odegrali ważną rolę w ekonomii zbawienia; wystarczy tutaj wspomnieć siostrę Mojżesza, którą nazywano Miriam (Lb 26, 59) lub Maria. Była ona ,pieśniarką duchową" wybawienia Izraela z niewoli egipskiej (zob. Wj 15, 20-21). Prorok Michaesz w paru słowach zebrał wspomnienie o niej: „(Ludu mój) Otom cię wywiódł z ziemi egipskiej, z domu niewoli wybawiłem ciebie i posłałem przed obliczem twoim Mcjżesza, Aarona i Miriam" (Mi 6, 4).

Brzmienie tego imienia zmieniało się w różnych epokach. Po powrocie $\mathrm{z}$ niewoli to samo imię wymawiano Mariam lub Maria. ${ }^{10}$

Znaczenie imienia Maryja próbowali wyjaśnić egzegeci i teolodzy. Jak nie jest łatwo wyprowadzić jego pochodzenie, to może świadczyć ten fakt, że pod koniec ubiegłego stulecia było około 60 hipotez wyjaśniających jego znaczenie. ${ }^{11}$ Dla przykładu podamy niektóre $z$ tych prób wyjaśnienia. I tak, jedni mówią, że imię Maryja pochodzi od hebrajskiego marom, co znaczy wyniosłość, wyniosły (a), inni wyprowadzają od słowa mara $h=$ buntowniczy, przeciwny, jeszcze inni od mara, co znaczy pełność, obfitość. ${ }^{12}$ Według Zorella można by

10 Zob. Ks. E. Dą browski, art., Maryja, Matka Bóża, w: Podręczna Encyklopedia Biblijna, t. II, s. 42.

11 Zob. O. A. Jankow ski, Ks. K. R omaniuk, Ks. L. Sta chowiak, Komentarz praktyczny do Nowego Testamentu, Poznań 1975, s. 233. ${ }_{12}$ Zob. Ks. J. E a ch, Ewangelia dziecięctwa Jezusa wedlug Łukasza (乇k 1-2), w: Studia $z$ biblistyki, t. I, Warszawa 1978, s. 269. 
mówić o pochodzeniu egipskim imienia Maryja od słowa merit= = umiłowana.

Ogólnie biorą, egzegeci i teolodzy przyjmują, że imię Maryja pochodzi od rdzenia wyrażającego idee upodobania, miłości. Stąd imię Maryja znaczyłoby tyle co „umiłowana przez Jahwe”.

\section{„BĄDŹ POZDROWIONA” (毛 1, 28)}

To krótkie lapidarne pozdrowienie zawiera w sobie dużo treści teologicznej. Nawiązuje do słów Boga, słów bardzo gorzkich wypowiedzianych do Ewy: „Obarczę cię niezmiernie wielkim trudem twej brzemienności, w bólu będziesz rodzila dzieci..." (Rdz 3, 16). Przeciwnie jest w scenie zwiastowania, Maryja słyszy słowa radości, które mieszczą się w tym pozdrowieniu. Bóg chce naprawić w Maryi plan nie zrealizowany w Ewie. W Maryi Ewa zostaje odrodzona, gdyż Maryja w swej doskonałości odzyskała to, co zostało utracone przez pierwszą matkę ludzkości (por. $\operatorname{Rdz} 3,15$ ).

Bóg przez Maryje rozpoczyna realizowanie mesjańskich przepowiedni i swego zbawczego planu względem ludzkości. ${ }^{13}$ Wielu współczesnych egzegetów idąc za myślą Ojców Greckich, sądzi, że to pozdrowienie anioła ma wymiar zbawczy, widząc w nim zaproszenie do radości mesjańskiej, o której mówią prorocy, a szczególnie Sofoniasz 3, 14--17. W wielu tekstach Starego Testamentu wezwanie to odnosi się do radości, która wynika $z$ ważnych dokonań w ekonomii zbawienia narodu wybranego (zob. Jl 2, 21, 23; So 3, 14). Jest ono adresowane do mieszkańców Jeruzalem, do Córek Syjonu, do środowiska, do którego przybywa Bóg, by wykonywać swą władzę królewską. Podobnie jest w ksiegach Nowego Testamentu, na co wskazuje wiele tekstów (zob. Ek 10; 20; Mt 5, 12; 2 Kor 13, 11; Flp 1, 18; 3, 1; 4, 4; 1-Tes 5,$16 ; 1 \mathrm{P} 4,13)$.

$\mathrm{Na}$ powód radości Maryi wskazują dalsze słowa wysłańca Bożego: „pełna łaski” (દk 1, 28). To napełnienie łaską wskazuje, że Maryja została wybrana przez Boga do nadzwyczajnej misji - do realizacji planow Nowego Przymierza. W Starym Testamencie słowo charitoō przyoiera różne znaczenia. I tak w Księdze Syracha 18, 17 oznacza człowieka łaskawego, ludzkiego, zaś w Ps 17 (18) słowo to zostało użyte na ónaczenie człowieka doskonałego. W tekście pozdrowienia anielskiego słowo charitoō jest użyte w participium perf. passivi charitômene. Gdybyśmy je tłumaczyli według Ef 1, 6, wtedy należałoby je rozumieć, że Maryja jest przedmiotem szczególnej łaskawości Bożej.

13 Zob. Ks. F. Gryglewicz, Ewangelia wedlug św. Eukasza, Poznań 1974, s. 91. 
Ale powstaje spontaniczne pytanie, czy takie tłumaczenie jest wystarczające? Wydaje się, że nie, gdyż Maryi przypisujemy pełnię łaski z racji jej Bożego macierzyństwa. Wielu Ojców Kościoła i pisarzy udowodniało tę prawdę powołując się na tekst $\mathrm{w}$ brzmieniu Wulgaty: gratia plena.

\section{„PAN Z TOBĄ” (Łk 1, 28)}

Pozdrowienie skierowane do Maryi, ma głęboki wymiar zbawczy. W tej formule „Pan z Tobą" mieści się wskazanie, że w tym momencie rozpoczyna się realizacja zbawienia, realizacja konkretna, związana ściśle $z$ faktem przymierza zawartym przez Boga $z$ narodem wybranym (por. $2 \mathrm{Sm} \mathrm{23,5).} \mathrm{To} \mathrm{pozdrowienie} \mathrm{stanowi} \mathrm{istotny} \mathrm{element}$ przymierza jakie Bóg zawiera z Dawidem. Wszelkie sukcesy Dawida były związane z tym, iż Pán był z nim, na co wskazują liczne opisy

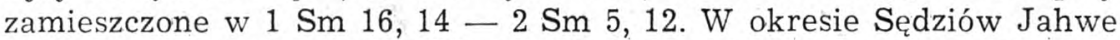
jest również z nimi (zob. Sdz 2, 18; 6, 12. 13. 16). Tę ideę obecności Boga $z$ poszczególnymi jednostkami, całym narodem można odnieść do najstarszych tradycji Izraela (zob. Rdz 26, 3a; 28, 15; 31, 3; 46, 4; $48,21)$.

$\mathrm{Z}$ tego, co powiedzieliśmy powyżej, można wyciągnąć wniosek, że tego, kogo Bóg powołał do niesienia pomocy jednostce czy narodowi, określano mianem „Bóg jest z nim”. Stąd użycie takiej formuły skierowanej pod adresem Maryi nawiązuje do przymierza zawartego przez Boga $z$ narodem wybranym. I w ten sposób Maryja została z Bożej woli włączona, więcej ściśle powiązana z zbawczym dziełem Bożym.

\section{„OTO POCZNIESZ I PORODZISZ SYNA” (Łk 1, 31)}

$\mathrm{Na}$ powyższe słowa anioła Maryja odpowiada pytając: „Jakże się to stanie, skoro nie znam męża?"' $(1,34)$. Dwa twierdzenia z Ek 1,34 i 37 wskazują, że Maryja jest dziewicą, nawiązując myślą do Iz 1, 14. Sw. Eukasz interpretuje Izajasza 7, 14 jako znak, że dziecię, które zrodzi Maryja, weźmie na siebie wypełnienie obietnic. Biblia Tysiaclecia (wydanie 3) do Łk 1, 34 daje taki komentarz, że jest to albo aluzja do tego, że Maryja, aczkolwiek już zaręczona, w chwili zwiastowania nie korzysta jeszcze $\mathrm{z}$ pełni praw małżeńskich i tylko tę sytuację ma na myśli, albo odwołuje się do wcześniej uczynionego i już obejmującego całe przyszłe życie Maryi postanowienia trwania w dziewictwie.

Punktem kulminacyjnym zwiastowania anielskiego są słowa: „Duch Święty zstąpi na Ciebie i moc Najwyższego osłoni Cię”. (Ek 1, 35). Spotykamy się tutaj z rolą Ducha Swiętego, który tworzy stały fundament ewangelii św. Łukasza. Jego działalność jest bardziej 
znacząca niż chrztu. Nazwany jest On „mocą Najwyższego". 'Ten Duch realizował plany Boże w wszystkich ważnych momentach narodu wybranego.

Wystarczy rzucić okiem na karty Pisma św. Już w Księdze Rodzaju 1, 2 czytamy: „Ziemia zaś była bezładem i pustkowiem: ciemność była nad powierzchnią wód, a Duch Boży unosił się nad wodami". ${ }^{14}$ Ten Duch Boży jest Duchem stwórezym Boga, który rodzi. życie w każdym stworzeniu. Tenże Duch jest pośrednikiem Boga, który objawia się przez historię i działa dla naszego zbawienia. Jego działanie dotyka każdego człowieka. ${ }^{15}$ I tak dla przykładu: Mojżesz, Jozue, królowie, prorocy są pełni Ducha. W 1 Księdze Samuela 10, 6 czytamy, że Saul znajduje się wśród proroków i wtedy opanowuje go "duch Jahwe" i zaczyna prorokować wraz z nimi. W szczególny sposób nosicielem Ducha będzie Mesjasz, jak czytamy u Izajasza 11, 2. Również na Słudze Jahwe spocznie Duch (zob. Iz 42).

W czasach mesjańskich w szczególny sposób zaznaczy się działanie Ducha w narodzie, na co wskazują prorocy: Ezechiel 36, 25-27, a szczególnie Joel 3,1-5. Nawet tradycja późno-judaistyczna wyra-żona w psalmach Salomona i innych pismach mówi, że przyszły Mesjasz będzie nosicielem Ducha. Poczęcie Mesjasza za sprawą Ducha jest początkiem ery mesjańskiej i eschatologicznego zbawienia. Poprzez poczęcie z Ducha Bóg pragnie zamanifestować swoją wolę przymierza i zbawienia. To ,zstąpienie Ducha" na człowieka oznacza specjalne posłannictwo osoby obdarzonej, która odtąd będzie działać mocą Bożą, a właściwie działać przez nią będzie sam Bóg. Paralelę do Ek 1, 35 znajdujemy w Dz 1, 8, gdzie jest mowa o tym, że Duch Swięty zstąpi na uczniów, aby byli świadkami Chrystusa „aż po krańce świata". Można by wnioskować, że u Łk 1, 35 jest zapowiedź, iż w Maryi spocznie Boża wszechmoc. Akcentuje się tutaj więcej sens teologiczny faktu.,zrodzenia" mocą Ducha Swiętego, podkreślając, że Jezus, który przyjdzie na świat w ludzkim ciele jest zapowiedzianym Mesjaszem, jest tym, który będzie kontynuowal dzieło zbawcze swego Ojca.

Częstochowa

KS. STANISEAW WEODARCZYK

$14 \mathrm{Na}$ temat rozwoju doktryny o Duchu Swiętym zob. D. Lys, „Rûach". Le Souffle dans l'Ancien Testament, Paris 1962; J. G uille t, La révélation progressive du Saint-Esprit dans Ecriture, "Lumen vitae" 28 (1953); 18-32; R. Koch, Der Gottesgeist und der Messias, "Biblica" 27 (1946), 241-268; O. A. Jankowski, Od Ducha Jahwe do Ducha Parakleta, RBL 1 (1977), 54-65.

15 Zob. K. H. Schelkle, La Madre del Salvatore. La figura di Maria nel Nuovo Testamento, Roma 1970, s. 33. 